Dept. of Food Control, Fac. of Vet. Med.,

Kafr El-Sheikh University, Kafr El-Sheikh 33516, Egypt.

\title{
DETECTION OF FOOT AND MOUTH DISEASE VIRUS (FMDV) IN MILK AND KAREISH CHEESE WITH TRIALS TO CONTROL IN MILK
}

(With 5 Tables)

By

\section{AZZA M.M. DEEB; H.F. AHMED; S.A.H. SALEM* and MERVAT I.M. EL-HASSANINE**}

*Dept. of Virology, Animal Health Research Institute, Dokki, Giza, Egypt **Animal Health Research Institute, Tanta Branch, Egypt.

(Received at 15/6/2010)

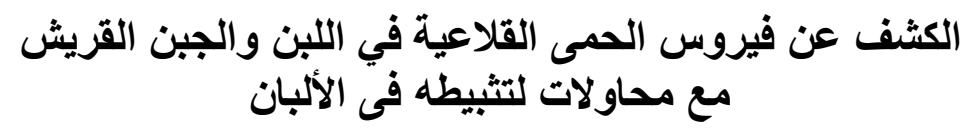

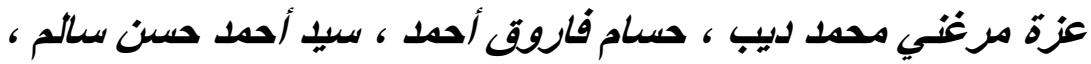
مرفت إبراميم الحسانين

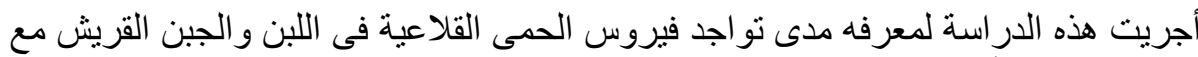

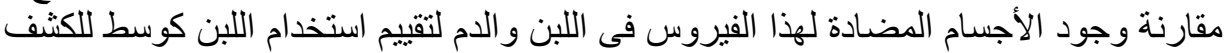

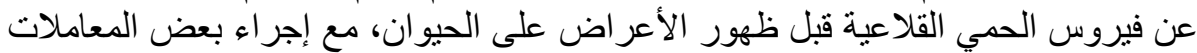

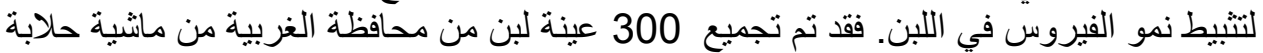

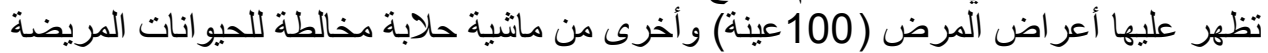

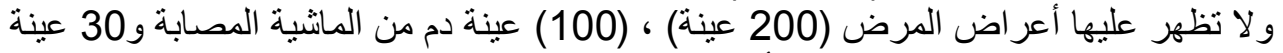

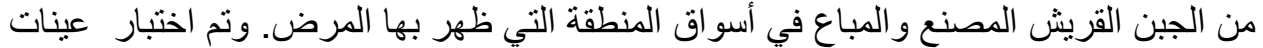

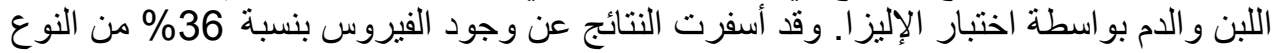

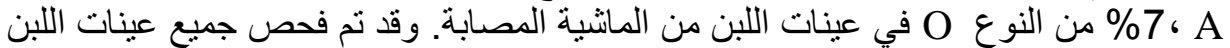

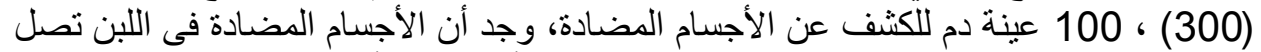

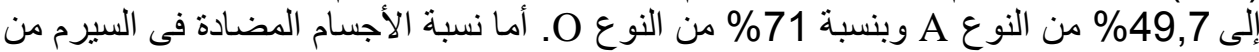

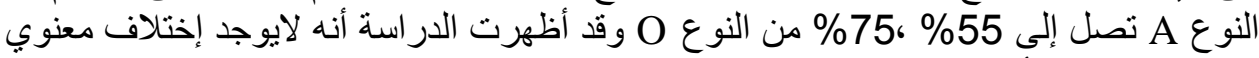

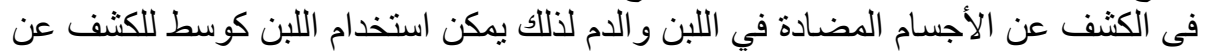

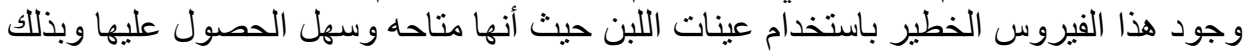

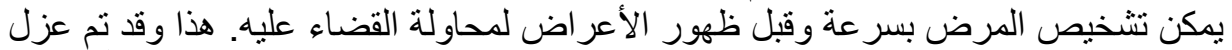

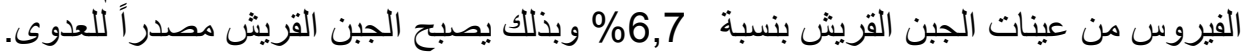

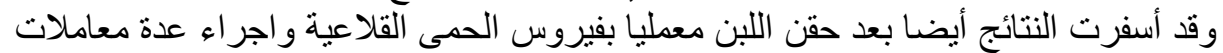

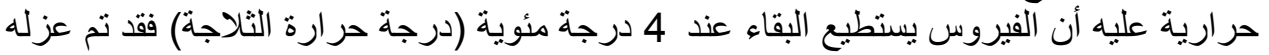




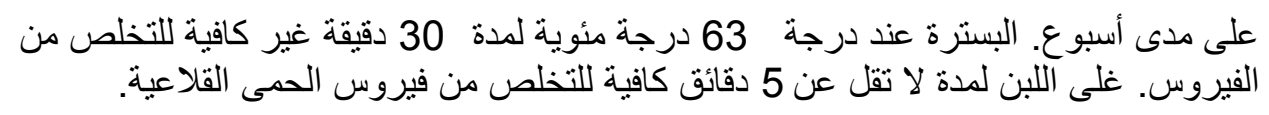

\section{SUMMARY}

The objectives of the present study were planned to detect Foot and Mouth Disease Virus (FMDV) in milk and kareish cheese; carry out comparison between the prevalence of antibodies against FMDV in milk and blood to evaluate using of milk as a medium for detection of the virus and control of the virus in milk. This study included a total of 300 milk samples (100 samples from diseased dairy cattle with apparent clinical signs and 200 samples from apparently healthy dairy cattle); 100 blood samples from diseased dairy cattle and 30 samples of skim milk soft cheese (kareish cheese). FMD viral antigens types $\mathrm{A}$ and $\mathrm{O}$ were detected in milk samples (from diseased dairy cattle) in percentages of 36 and $7 \%$, respectively. The antibodies against FMDV types $\mathrm{A}$ and $\mathrm{O}$ could be detected in milk samples from diseased dairy cattle in percentages of 40 and $68 \%$ and 54.5 and $72.5 \%$ in the examined milk samples obtained from apparently healthy dairy cattle, with total percentages of 49.7 and $71 \%$, respectively. The antibodies against FMDV type A could be detected in blood samples in a percentage of 55 and type $\mathrm{O}$ by $75 \%$. FMDV was detected in 2 samples (6.7\%) of the examined kareish cheese collected from the same infected area. FMDV could be isolated from refrigerated milk at $4^{\circ} \mathrm{C}$ for 7 dayes and could survive pasteurization of milk at $63^{\circ} \mathrm{C}$ for 30 minutes, but could not be detected in milk boiled for 5 minutes. In conclusion, the results of the present investigation indicate that the milk is an ideal medium for preclinical diagnosis of FMDV. Milk used for manufacturing of dairy products must be subjected to boiling for at least 5 minutes to control the spreading of FMD virus.

Key words: Virology, foot and mouth disease, milk, kareish cheese

\section{INTRODUCTION}

Foot and Mouth Disease Virus (FMDV) is not only a public health threat, but also, is highly contagious to all cloven-hoofed animals (Callis et al., 1968; Callens and De Clercq, 1997). The virus has seven serotypes [A, O, C, Asia 1, and Southern African Territories (SAT) 1, 2, and 3] and more than 60 subtypes. The small non-enveloped virus is a single-stranded positive-sense RNA virus belonging to the genus Aphthovirus, the family Picornaviridae. FMDV leaves mature animals debilitated and is sometimes 
fatal to the young. The disease is characterized by fever, blister-like lesions followed by erosions on the tongue and lips, in the mouth, on the teats, and between the hooves. It reduces the commercial value of dairy cattle by reducing milk yield. It may be spread by aerosol, direct contact with infected animals, or ingestion of contaminated milk or meat products or it may be transmitted by shoes, truck tires, and other inanimate objects in contact with the virus; birds; and rodents (APHIS, 2001).

FMDV replicates in the mammary gland of infected animals and is shed into the milk after being incorporated to the protein micelles and fat droplets up to $33 \mathrm{~h}$ before appearance of clinical signs of the disease in dairy cows. In extreme cases, signs of the disease may not appear for up to 14 days, during this time, raw milk can serve as a vector for spread of the disease both at the farm and during transport to processing plant. Raw milk and milk products have the potential to cause infection (Blackwell et al., 1981). Moreover, FMDV could survive in the milk of infected cows after high temperature-short time (HTST) pasteurization (Blackwell and Hyde, 1976) as well as in dairy products such as butter, casein, cheese and sweet whey after various manufacturing processes (Blackwell, 1981; Aly and Gaber, 2007).

Milk is an ideal medium for laboratory diagnosis of FMDV because, it is readily available in quantity and easily collected. Further benefit to detect the presence of FMD virus in milk, is its potential use as a preclinical diagnostic tool (Armstrong et al., 2000). Early detection of FMD virus is essential for effective control of the disease, which requires a rapid and sensitive method of diagnosis. In addition to the classical techniques of virus isolation in tissue culture, detection of antigen by Enzyme-Linked Immunosorbent Assay (ELISA) has replaced the complement fixation test as a routine method of choice (Kitching, 1992).

The present study is based on notification of some cases of FMD during 2007 outbreak and followed up reports in EL- Gharbia Governorate, Egypt. Therefore, the present study was planned to detect FMD viral antigens type $\mathrm{A}$ and $\mathrm{O}$ in milk by Enzyme Linked Immunosorbent Assay (ELISA) standard indirect sandwich ELISA; antibodies against FMDV types $\mathrm{A}$ and $\mathrm{O}$ in milk and blood serum by liquid phase blocking ELISA; FMD viral antigens in skim milk soft cheese (kareish cheese) by isolation on tissue culture (TC) and detection of cytopathic effect (CPE); and experimental work to control spreading of FMD virus through milk.

\section{MATERIALS and METHODS}

\section{Collection and preparation of samples (OIE, 2002).}




\subsection{Milk samples}

One hundred individual raw milk samples were obtained from diseased dairy cattle with clinical signs of FMD (the samples divided into two parts, one part for detection of antibodies against FMDV; and the other part for detection of FMD antigens), and two hundred individual raw milk samples were obtained from apparently healthy dairy cattle. All samples were collected from small holder dairy farms from notified area in El-Gharbia Governorate, Egypt under hygienic condition in sterile tubes (Venoject). The samples were immediately placed in ice box and sent to the laboratory. Rennin enzyme $1 \%$ was added for each sample, and then incubated at $37^{\circ} \mathrm{C}$ until clotting. The samples were subjected for centrifugation at $1500 \mathrm{rpm}$ for 10 minutes. Milk whey supernatant (300 samples) were stored in sterile tube at $\left(-20^{\circ} \mathrm{C}\right)$ until tested for detection of antibodies against FMDV types $\mathrm{A}$ and $\mathrm{O}$. The other part of milk samples from diseased dairy cattle (100 samples) were stored at $\left(-20^{\circ} \mathrm{C}\right)$ in the form of whole milk for detection of FMD viral antigens.

\subsection{Blood samples}

One hundred individual blood samples were collected from jugular vein of the same diseased dairy cattle in EL-Gharbia Governorate, Egypt under hygienic conditions by a sterile $5 \mathrm{ml}$ syringe. The samples were kept in sterile tube and left at room temperature for one hour until the clot begins to contract; the clot was ringed round with a sterile rod. The tubes then were placed at $4{ }^{\circ} \mathrm{C}$ for $16 \mathrm{~h}$. The samples were centrifuged at 1500 rpm for 10 minute. The serum was decanted and stored frozen at $\left(-20^{\circ} \mathrm{C}\right)$ until tested for detection of antibodies against FMDV types A and O.

\subsection{Skim milk soft cheese samples (Kareish cheese)}

30 samples of kareish cheese were collected from the markets of the same infected area in EL-Gharbia Governorate, Egypt. The samples were placed in ice box and sent to the laboratory with a minimum of delay. The cheese samples were homogenized and diluted 1:4 w/v with phosphate buffer solution (PBS). The suspension of each sample was centrifuged at $1000 \mathrm{rpm}$ for 10 minutes; the supernatant fluid was aspirated for FMDV isolation on tissue culture.

\subsection{Milk for experimental work}

$300 \mathrm{ml}$ of fresh milk sample was collected from healthy buffalo previously tested for FMD viral antigen in its milk and show negative result; the sample sent to the laboratory in ice box for experimental work.

\section{FMD Virus}

The virus which had been used in this study was locally isolated virus (type O) and obtained from Animal Health Research Institute, Dokki, Giza, Egypt. 


\section{Cell culture}

Baby hamster kidney cell line $\left(\mathrm{BHK}_{21}\right)$ clone 13-cells were received from PADUA, Italy and maintained in the Virology Department, Animal Health Research Institute, Dokki, Egypt, using Eagles medium with 10\% sterile bovine serum as described by MacPherson and Stocker (1962).

\section{Indirect sandwich Enzyme Linked Immunosorbent Assay (ELISA) for detection of antigens of FMD Virus types A and $O$.}

The kit was based on a standard indirect sandwich ELISA technique to determine the presence of FMD viral antigens in whole milk samples as described by Roeder and Le Blanc Smith (1987); Ferris and Dawson (1988). The ELISA reagents were prepared according to Voller et al. (1976).

\section{Liquid phase blocking ELISA (L.P.B.E) for detection of antibodies against FMD virus types $A$ and $O$.}

The kit was liquid phase blocking ELISA technique for detection of antibodies against FMDV in milk whey and blood serum samples as described by Hamblin et al. (1986 a, b).

\section{Virus isolation from kareish cheese samples}

Confluent $\mathrm{BHK}_{21}$ cells were used for virus isolation (in 96 well microtiter tissue culture plate). Growth medium was decanted. $50 \mu 1$ of samples suspension were inoculated (4 wells for each sample) and equal amounts of the FMDV using 100 TCID $_{50}$ (Tissue Culture Infective Dose) were added to 8 wells (control wells). The inoculated plates were incubated at $37^{\circ} \mathrm{C}$ in $\mathrm{CO}_{2}$ incubator for 1 hour. Maintenance media $(100 \mu \mathrm{l} /$ well) was then added, and the plates were examined daily with inverted light microscope until appearance of characteristic CPE. Non infected $\mathrm{BHK}_{21}$ cells were considered as negative control.

\section{Experimental work}

Milk sample was divided into 3 portions (100 ml each). Each milk portion was injected experimentally with $10 \mathrm{ml}$ of FMD virus type $\mathrm{O}$ titer $10^{6} \mathrm{TCID} 50 / \mathrm{ml}$. The inoculated milk portions were kept under different degree of temperatures: at $+4^{\circ} \mathrm{C}$; at $63^{\circ} \mathrm{C}$ for 30 minutes (L.T.L.T.) and at boiling degree, for 5 minutes. $50 \mu$ of each sample were inoculated in tissue culture and examined for cytopathic effect (CPE).

\section{RESULTS}

Table 1: Foot and mouth disease (FMD) viral antigen types $A$ and $O$ in milk samples of diseased dairy cattle (indirect sandwich ELISA). 


\begin{tabular}{|l|c|c|c|}
\hline \multirow{2}{*}{ (FMD) viral antigen in milk samples } & \multirow{2}{*}{$\begin{array}{c}\text { No. of } \\
\text { examined } \\
\text { samples }\end{array}$} & No. & $\%$ \\
\cline { 3 - 4 } & 100 & 36 & 36 \\
\hline Type (A) & 100 & 7 & 7 \\
\hline Type (O) & &
\end{tabular}

Table 2: Screening of antibodies against FMD virus type $\mathrm{A}$ and $\mathrm{O}$ in milk [liquid phase blocking ELISA (LPBE)].

\begin{tabular}{|c|c|c|c|c|c|}
\hline \multirow{3}{*}{$\begin{array}{c}\text { Types of examined } \\
\text { samples }\end{array}$} & \multirow{3}{*}{$\begin{array}{l}\text { No. of } \\
\text { examined } \\
\text { samples }\end{array}$} & \multicolumn{4}{|c|}{ Antibodies against FMD Virus in milk whey } \\
\hline & & \multicolumn{2}{|c|}{$\begin{array}{c}\text { Antibodies type A } \\
\text { positive samples }\end{array}$} & \multicolumn{2}{|c|}{$\begin{array}{l}\text { Antibodies type } O \\
\text { positive samples }\end{array}$} \\
\hline & & No. & $\%$ & No. & $\%$ \\
\hline $\begin{array}{l}\text { Milk samples from } \\
\text { diseased dairy cattle }\end{array}$ & 100 & 40 & 40 & 68 & 68 \\
\hline $\begin{array}{l}\text { Milk samples from } \\
\text { apparently healthy dairy } \\
\text { cattle }\end{array}$ & 200 & 109 & 54.5 & 145 & 72.5 \\
\hline Total & 300 & 149 & 49.7 & 213 & 71 \\
\hline
\end{tabular}

Table 3: Matching between antibodies against FMD Virus type A and $O$ in milk and blood from the diseased dairy cattle.

\begin{tabular}{|c|c|c|c|c|c|}
\hline \multirow{3}{*}{$\begin{array}{l}\text { Types of } \\
\text { Antibodies }\end{array}$} & \multicolumn{4}{|c|}{ Types of sample } & \multirow{3}{*}{$P$} \\
\hline & \multicolumn{2}{|c|}{$\begin{array}{l}\text { Milk samples } \\
\qquad(\mathrm{n}=100)\end{array}$} & \multicolumn{2}{|c|}{$\begin{array}{l}\text { Blood samples } \\
\qquad(\mathrm{n}=100)\end{array}$} & \\
\hline & $\begin{array}{c}\text { No of +ve } \\
\text { samples }\end{array}$ & $\begin{array}{c}\% \text { of +ve } \\
\text { samples }\end{array}$ & $\begin{array}{c}\text { No of +ve } \\
\text { samples }\end{array}$ & $\begin{array}{c}\% \text { of +ve } \\
\text { samples }\end{array}$ & \\
\hline $\begin{array}{l}\text { Antibodies } \\
\text { type A }\end{array}$ & 40 & 40 & 55 & 55 & $0.0472^{*}$ \\
\hline $\begin{array}{c}\text { Antibodies } \\
\text { type } O\end{array}$ & 68 & 68 & 75 & 75 & 0.3474 \\
\hline
\end{tabular}

$P^{*}$ : Significant

Table 4: Isolation of FMD Virus from kareish cheese collected from markets at the same infecteded area by inoculation on BHK cells.

\begin{tabular}{|l|l|c|c|} 
Type of sample & No. of examined samples & $\begin{array}{c}\text { CPE +ve } \\
\text { samples }\end{array}$ & $\%$ \\
\hline
\end{tabular}




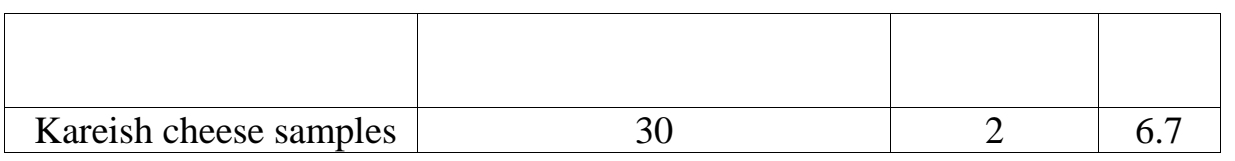

$\mathrm{CPE}=$ cytopathic effect $\quad \mathrm{BHK}=$ Baby Hamster Kidney

Table 5: Survival of FMD Virus in cooled, heat treated milk after experimental inoculation with FMD Virus $(\mathrm{O})$.

\begin{tabular}{|c|c|c|c|}
\hline Days & Milk kept at $4^{\circ} \mathrm{C}$ & Milk boiled for 5 min & $\begin{array}{c}\text { Milk pasteurized at } \\
63^{\circ} \mathrm{C} / 30 \mathrm{~min} \text { (LTLT) }\end{array}$ \\
\hline 1 & + & - & + \\
\hline 2 & + & & \\
\hline 3 & + & & \\
\hline 4 & + & & \\
\hline 5 & + & & \\
\hline 6 & + & & \\
\hline 7 & + & & \\
\hline
\end{tabular}

\section{DISCUSSION}

The present study was planned to determine the usefulness of milk as a diagnostic tool for detection of FMDV. The results pointed out that, out of the 100 milk samples collected from diseased dairy cattle from notified cases in El-Gharbia Governorate in winter 2007, the antigens of FMDV types $\mathrm{A}$ and $\mathrm{O}$ could be detected in 36 and 7 milk samples, respectively (Table 1). Shedding of the virus in milk samples was previously reported by Blackwell (1981) and Reid et al. (2006). They reported that, FMDV replicated in mammary glands of infected lactating animals and shed into milk two days before clinical signs of disease appeared through 14 days post infection. During this period, milk act as a vector for spreading of the disease in the farm and during transportation to the processing plant. Collectively, the presence of FMDV in milk is considered as a preclinical diagnostic tool as mentioned by Blackwell et al. (1982) and Tomasula and Konstance (2004).

The high incidence of FMD viral antigens may be due to bad hygienic measures. Also, the infection with type A was more than that of type $\mathrm{O}$, this may be due to previous intensive vaccination program against FMDV type $\mathrm{O}$ in Egypt.

The antibodies against FMDV type A could be detected in $40 \%$ of examined milk samples collected from diseased dairy cattle and $54.5 \%$ of tested milk samples obtained from apparently healthy dairy cattle with total percentage of $49.7 \%$. Moreover, the antibodies against FMDV type $\mathrm{O}$ were detected in 68 and $72.5 \%$ of evaluated milk samples, respectively with total 
percentage of $71 \%$ (Table 2).

Presence of antibodies against FMDV type A in examined milk samples may be attributed to early stage of natural infection by FMDV type A. Nearly similar result was recorded by Sarma et al. (2004), they demonstrated that antibodies against FMDV in milk appeared early before fever and other clinical signs. Prevalence of antibodies against FMDV type $\mathrm{O}$ were higher than that of antibodies against FMDV type A, suggesting intensive control measures against FMDV type $\mathrm{O}$ was applied in ElGharbia Governorate by national regular vaccination. These results were supported by those reported by Ahmed et al. (1995); Armstrong et al. (2000); Basyouni (2008).

The antibodies against FMDV serotypes $\mathrm{A}$ and $\mathrm{O}$ were detected in 55 and $75 \%$ of the evaluated blood samples collected from the same diseased dairy cattle (Table 3). The higher prevalence of antibodies against FMDV serotypes $\mathrm{A}$ and $\mathrm{O}$ indicate and confirm that FMD outbreak occurred at El-Gharbia Governorate in winter 2007 caused by both types of virus A and O. Similar results were reported by Basyouni (2008).

The data presented in Table (3) showed the comparison between the prevalence of antibodies against FMDV serotypes $\mathrm{A}$ and $\mathrm{O}$ in milk and blood samples from the same diseased dairy cattle. It is evident that, there was no significant difference in detection of antibodies against FMDV type $\mathrm{O}$ in milk and blood samples $(\mathrm{P}=0.3474)$, so milk can be used for detection of the infection with FMDV type O. While; a significant difference in detection of antibodies against FMDV type A in milk and blood samples was observed $\left(P=0.0472^{*}\right)$. The results act as a guide for that serum is the mirror of diagnosis of infection (Cottral, 1992). Milk is one of the body fluids which can be used as a base for FMDV investigation. The results obtained were in accordance to the results recorded by Armstrong et al. (2000). So the detection of antibodies against FMDV emphasizes the importance of using milk as a diagnostic aid for FMD diagnosis because it is readily available in quantity and easily to be collected (Haas, 2004). Earlier diagnosis of FMDV infection by examination of milk from premises at risk and consequent earlier destruction of sources of viral dissemination can exert a considerable effect in limiting the extent of an outbreak.

It is evident from the obtained results that, the standard indirect sandwich ELISA technique which used for detection of FMD viral antigens in milk samples and liquid phase blocking ELISA technique for detection of antibodies against FMDV in milk whey are highly sensitive and suitable for routine diagnosis and typing of FMDV of all types. Similar results were 
recorded by Roeder and Le Blanc Smith (1987); Ferris and Dawson (1988). They concluded that ELISA is more sensitive, accurate and rapid technique than complement fixation test for detection of FMDV and its antibodies.

FMDV could be isolated from $6.7 \%$ (2 out of 30 samples) of examined kareish cheese collected from the same examined area at El-Gharbia Governorate using Baby Hamster Kidney (BHK) cell culture (Table 4). Isolation of FMDV from kareish cheese indicated that FMDV could remain viable in kareish cheese and survive the manufacturing processes. This finding coincided with that recorded by Nardelli and Zoletto (1986); Ahmed et al. (1995); Emery (2002); Kawther et al. (2008). Presence of FMDV in kareish cheese is attributed to its preparation from infected unheated milk. The infected milk may be processed and distributed before detection of the FMDV and play a role in the spread of the disease; so early detection is essential for effective control of the FMD.

FMDV could be detected after experimental contamination and isolation by using BHK cell culture and detection of CPE in milk sample kept at $4{ }^{\circ} \mathrm{C}$ for 7 days. Thermal processing of milk, after experimental contamination, at low temperature long time pasteurization (LTLT) $63^{\circ} \mathrm{C}$ for $30 \mathrm{~min}$ could not destroy the virus and indicated that FMDV could survive and remained viable in pasteurized milk. Moreover, the virus failed to be detected in milk sample boiled for $5 \mathrm{~min}$ (Table 5). Thermal resistance of FMD virus in milk must be discussed to identify the risks associated with ingestion of infected milk, and to put a strategy to prevent the spread of FMDV. Experimental contamination of milk and keeping at $4{ }^{\circ} \mathrm{C}$ for 7 days indicated that cooling of infected milk and milk products with FMDV has no significant effect in virus control. These results are supported with that reported by Basyouni (2008) which reported that FMDV could survive up to 30 days in refrigerated milk.

Detection of FMDV in experimentally infected milk and subjected to thermal processing at LTLT pasteurization indicated that the virus could survive and remain viable in pasteurized milk. This result mostly agreed with those reported by Aly and Gaber (2007); Tomasula et al. (2007). They concluded that FMDV in milk could survive intensive high temperature treatment because the virus was protected by fat or protein in milk. These results disagreed with those obtained by Bohm (1982) who concluded that spread of FMDV through milk or milk products was unlikely and provided that the virus could be inactivated in infected milk pasteurized at $63{ }^{\circ} \mathrm{C}$ or $72{ }^{\circ} \mathrm{C}$ for more than or equal to 40 seconds.

From the above results it can be concluded that cooled milk, pasteurized milk, soft and kareish cheese may act as vectors for transmission of the virus. Transmission of FMDV through milk is probably 
evidence during a series of outbreaks.

On contrast, the virus could not withstand boiling for 5 minutes. This result was in agreement with those concluded by Aly and Gaber (2007) and Tomasula et al. (2007). Therefore, boiling of milk from infected animals for 5 minutes render it safe. Meanwhile, milk used for processing of dairy products must be subjected to boiling for at least 5 minutes.

The major hazard can be controlled by the cooperation and application of precautions by the animal health authorities and those involved in dairy industry. In addition regular vaccination of animals against FMDV and proper boiling of milk in farms before delivery to consumers and exhibition of marketing raw milk. Also, by routine examination of dairy products imported from countries specially those where FMD is enzootic.

In conclusion, the results of the present investigation indicate that the milk is an ideal medium for preclinical diagnosis of FMDV. Milk used for manufacturing of dairy products must be subjected to boiling for at least 5 minutes to control the spreading of FMDV.

\section{REFERENCES}

Ahmed, H.F.; EL-Sawalhy, A.A.; Nakashley, S.H. and Salem, S.A.H. (1995): Detection of antibodies against FMDV in milk by indirect ELISA and survival of the virus in heat treated milk and some dairy products. J. Egyptian Vet. Med. Assoc., 55, 1-2.

8 Aly, S.A. and Gaber, A.S. (2007): Inactivation of Foot and Mouth Disease Virus in milk and milk products. D) Milchwissenschaft, 62 (1): 3-5.

APHIS "Animal and Plant Health Inspection Service" (2001): Foot-andMouth Disease Emergency Disease Guidelines. USDA, Marketing and Regulatory Programs, Veterinary Services, Riverdale, MD.

Armstrong, R.M.; Mathew, E.S. and Mackay, D.K.J. (2000): Validation of the specific isotype assay to detect antibodies against Footand-Mouth Disease Virus in bovine milk. \&J. Virol. Methods, 85 (1/2): 193-201.

Basyouni, Y.M. (2008): Publich health importance of FMD, epidemiology. M.V. Sc. Thesis, Hygiene and Preventive Medicine, Fac. Vet. Med., Kafr El-Sheikh University, Egypt.

Blackwell, J.H. (1981): Association of foot and mouth disease virus with bovine milk constituents. Dissertation Abstracts International, B, 
42,5,1806. Dairy Sci Abst,44,7.550(1982).

Blackwell, J.H. and Hyde, J.L. (1976): Effect of heat on Foot and Mouth Disease Virus (FMDV) in the components of milk from FMDV infected cows. J. Hyg, Camb, 77: 77-83.

Blackwell, J.H.; Wool, S. and Kosikowski, F.V. (1981): Vesicular exocytosis of Foot-and-Mouth Disease Virus from mammary gland secretory epithelium of infected cows. J. Gen. Virol., 56: 207-212.

8 Blackwell, J.H.; McKercher, P.D.; Kosikowski, F.V.; Carmichael, L.E. and Gorewit, R.C. (1982): 8 Concentration of Foot-and-Mouth Disease Virus in milk of cows infected under simulated field conditions. \&J. Dairy Sci., 65 (8): 1624-1631

Bohm, H.O. (1982): Inactivation of Foot-and-Mouth Disease Virus in casein, milk and milk products. \$Deutsche Molkerei-Zeitung, 103, 68-72.

Callens, M. and De Clercq, K. (1997): Differentiation of the seven serotypes of Foot-and-Mouth Disease Virus by reverse transcriptase polymerase chain reaction. J. Virol. Methods 67: 35-44.

Callis, J.J.; Coercer, P.D. and Graves, J.H. (1968): Foot-and-Mouth Disease-A review. J. AVMA, 153:1798-1802.

Cottral, G.E. (1992): Persistence of FMDV in animals. Off. Int. Epizoot., 71: 549.

8 Emery, D.L. (2002): An application of import risk analysis to Foot and Mouth Disease Virus (FMDV) in dairy products for human consumption. Dulletin Inter. Dairy Federation, 372: 10-14.

Ferris, N.D. and Dawson, M. (1988): Routine application of enzymelinked immunosorbent assay in comparison with complement fixation for the diagnosis of Food-and-Mouth and swine vesicular diseases. Vet. Microbiol., 16: 201-209.

Haas, B. (2004): Inactivation of Foot-and-Mouth Disease Virus in milk. $\$$ Bulletin Inter. Dairy Federation, 392: 77-83.

Hamblin, C.; Barnett, I.T.R. and Hedger, R.S. (1986 a): A new enzymelinked immunosorbent assay (ELISA) for the detection of antibodies against Food-and-Mouth Disease Virus. 1. Development and methods of ELISA. J. Immunol. Methods, 93: 115-121.

Hamblin, C.; Barnett, I.T.R. and Hedger, R.S. (1986 b): A new enzymelinked immunosorbent assay (ELISA) for the detection of antibodies against Food-and-Mouth Disease Virus. 11. Applicatio. J. Immunol. Methods, 93: 123-129. 
Kawther, S. Zaher; Ahmed, W.M.; Sohier, M. Syame and El-Hewairy, H.M. (2008): Detection of health hazard-food born viruses in animal products anticipated for human consumption. Global Veterinaria, 2: 192-197.

Kitching, R.P. (1992): The application of biotechnology to the control of Foot-and-Mouth Disease Virus. Br. Vet. J., 148: 375-388.

Macpherson, I.A. and Stocker, M. (1962): Polyoma transmission hamster cell clones: An investigation of genetic factors affecting cell competence. Virol., 16: 147-151.

Nardelli, S. and Zoletto, R. (1986): Survival of foot and mouth disease virus in cows' milk and milk products. \$Clinica Veterinaria,. 109 (4): 281-287.

OIE "Office International de Epizooties" (2002): Manual of Diagnostic Tests and Vaccines for Terrestrial Animals, $5^{\text {th }}$ edition, OIE Ed.

8 Reid, S.M.; Parida, S.; King, D.P.; Hutchings, G.H.; Shaw, A.E.; Ferris, N.P.; Zhang ZhiDong; Hillerton, J.E. and Paton, D.J. (2006): Utility of automated real-time RT-PCR for the detection of Foot and Mouth Disease Virus excreted in milk. \$Vet. Res., 37: $121-132$.

Roeder, P.L. and Le Blanc Smith, P.M. (1987): Detection and typing of FMDV by ELISA: a sensitive, rapid and reliable technique for primary diagnosis. Res. Vet. Sci., 43 (2): 225-232.

Sarma, D.K.; Kalita, K. and Sutopa, D. (2004): Outbreak of Foot and Mouth Disease due to virus type 'A' and loss of milk production. Blue Cross Book 22, 21-23.

Tomasula, P.M. and Konstance, R.P. (2004): The Survival of Foot-andMouth Disease Virus in Raw and Pasteurized Milk and Milk Products. American Dairy Science Association. US Department of Agriculture, Agricultural Research Service, Dairy Processing and Products Research Unit, Eastern Regional Research Center, J. Dairy Sci., 87: 1115-1121.

Tomasula, P.M.; Kozempel, M.F.; Konstance, R.P.; Gregg, D.; Boettcher, S.; Baxt, B. and Rodriguez, L.L. (2007): Thermal inactivation of Foot-and-Mouth Disease Virus in milk using high-temperature, short-time pasteurization. \&J. Dairy Sci., 90 (7): 3202-3211.

Voller, A.; Bidwell, D.E. and Brtlett, A. (1976): Enzyme immunoassays in diagnostic medicine. Theory and practice Bull. World Health Organ. 53: 55-65. 